
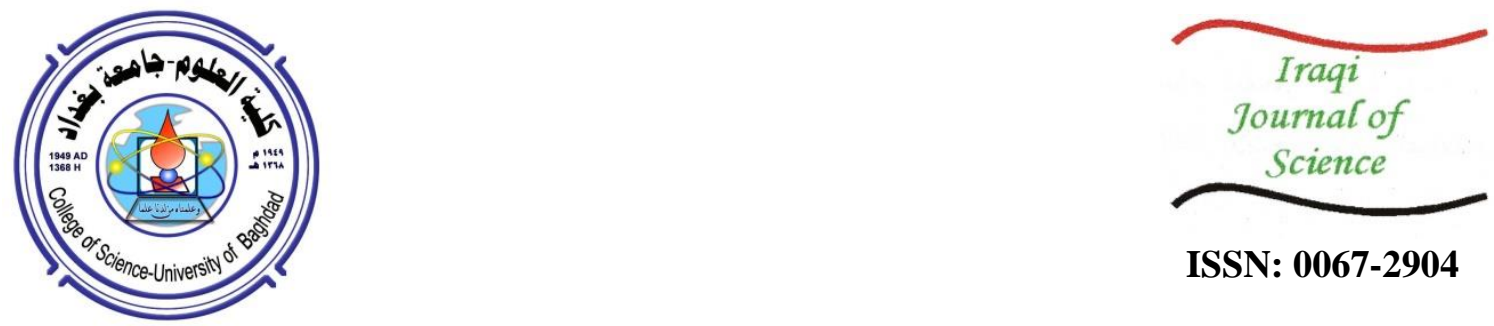

ISSN: 0067-2904

\title{
Isolation and identification of phosphate solubilizing bacteria and evaluate its effect on of Mung bean (Vigna radita [L.] R.Wilczek) growth
}

\author{
Yusur Ramzi, Hutaf A. A. Alsalim* \\ Department of Biotechnology, College of Science, University of Baghdad, Baghdad, Iraq
}

\begin{abstract}
Sixteen soil samples were collected from wheat, barley and yellow corn rhizosphere in Abu-Ghraib, Aqraqof, Latifieh,Tarmiah, Jadriya and of Agriculture in Baghdad university/ Baghdad city. The results found nine phosphate solubilizing bacteria (PSB) isolates (Y1, Y2, Y3, Y4, Y5, Y6, Y7, Y8, Y9), formed clear zones on National Botanical Research Institute's (NBRIP) agar. The solubility index (SI) of PSB isolates ranged from 2.00 to 3.66. Y4 have the highest SI (3.66) followed by Y3 and Y6 (3.33). Phosphate solubilization abilities varying from (20.10-39.00 $\left.\mu \mathrm{g} \cdot \mathrm{ml}^{-1}\right)$, Y4 was the highest $\left(39.00 \mu \mathrm{g} \cdot \mathrm{ml}^{-1}\right)$ followed by Y3 $\left(37.00 \mu \mathrm{g} \cdot \mathrm{ml}^{-1}\right)$. The results of hydrolytic enzymes production showed that almost all nine isolates are able to produce protease and pectinase, while $\mathrm{Y} 1$ and $\mathrm{Y} 2$ showed negative results in cellulase production. Maximum ability for hydrogen cyanide (HCN) and indole acetic acid (IAA) production were showed byY3 and Y4 isolates. The isolate Y4 was found to be the most efficient isolate, so it was selected identified as Bacillus cereus using biochemical tests confirmed by VITEC 2 compact system. The results of High performance liquid chromatography (HPLC) revealed that Bacillus cereus produce oxalic acid (2.996), citric acid (9.117) and malic acid (3.734). Bacillus cereus (Y4) enhanced the growth of mung bean plants. A significant increase in branches number $(12.33)$, plant length $(83.0 \mathrm{~cm})$, fresh weight $(27.25 \mathrm{~g})$ and dry weight $(1.427 \mathrm{~g})$ were obtained compared with control treatments. The main objective of this study is to isolate PSB and evaluate their roles in plant growth promotion. The results showed the high phosphate solubilization efficiency of PSB isolates and the identified isolates was found to be good enough for plant growth promoting.
\end{abstract}

Keywords: Bacillus cereus, hydrolytic enzyme, organic acid production, phosphate solubilizing bacteria, plant growth promoter.

\section{عزل وتثخيص البكتريا المذيبة للفوسفات وتقييم تأثيرها في نمو نبات الماش (Vigna radita [L.] R.Wilczek)}

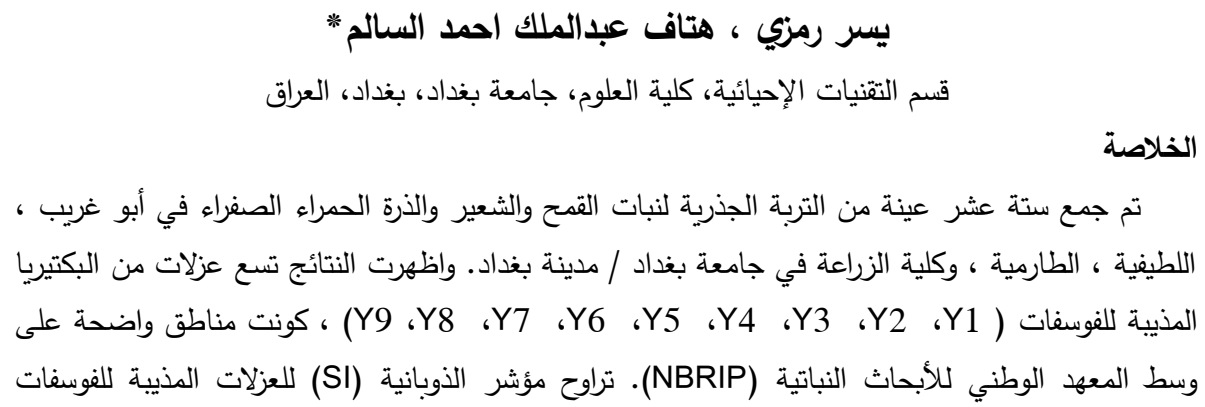


(3.33) من 2.00 إلى 3.66. تمتلك العزلة Y4 أعلى مؤشر ذوبانية (3.66) يليها (PSB)

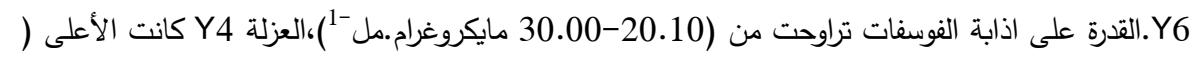

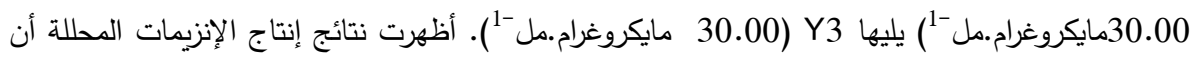

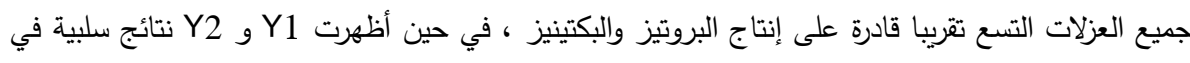

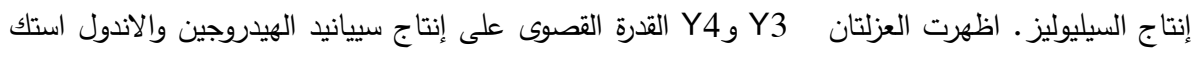

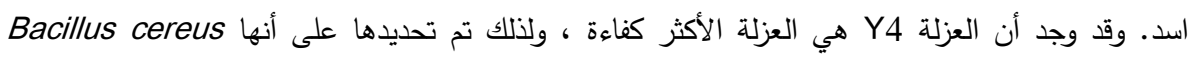

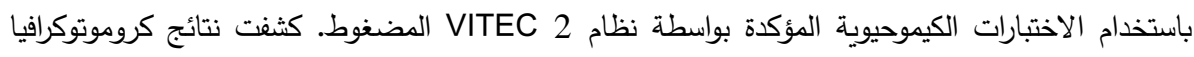

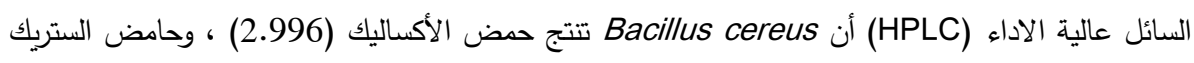

(9.117) وحمض الماليك (3.734). عززت عزلة Bacillus cereus نمو نبات الماش. وتم الحصول

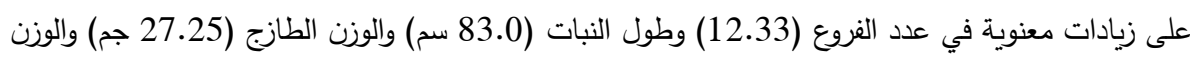

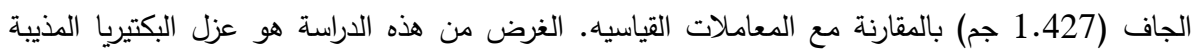

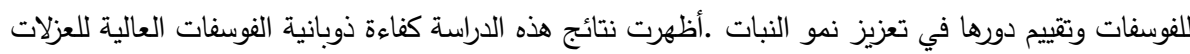

الدذيبة للفوسفات وان العزلة المشخصة كانت جيدة بدرجة كافية في تعزيز نمو النبات.

\section{Introduction}

Phosphor (P) availability to plant is limited despite its higher content in soil, particularly in tropical soils.The rapid conversion of supplied chemical phosphate fertilizers into insoluble phosphate sources leads to regularly applying $\mathrm{P}$ fertilizers, which are costly and environmentally undesirable. Therefore, some innovative technologies tend to develop and focus on the use of soil microbes, particularly PSB as a biofertilizers. phosphate solubilizing bacteria (PSB) which belongs to genera Agrobacterium, Arthrobacter, Azotobacter, Rhizobium, Erwinia, Enterobacter, Pseudomonas, and Bacillus shave the ability to solubilize insoluble $\mathrm{P}$ and supply plants with available phosphorus by producing various organic acids, mineral acids, siderophores, protons, humic substances, $\mathrm{CO}_{2}$ and $\mathrm{H}_{2} \mathrm{~S}$ [1].

Biofertilizers have varies mechanisms for enhancing plant growth, such as solubilizing insoluble phosphate, biological nitrogen fixation, and inhibit the growth of phytopathogens by the production of hydrocyanic acid (HCN), protease, cellulose and pectinase, when inoculated to seeds, root or into the soil $[2,3]$.

Various strategies have been demonstrated for solubilization of phosphates in liquid medium $[4,5]$. One of the most accepted theory is secretion of low molecular mass organic acids (OA) by microorganisms. In varies studies, the presence of organic acids (i.e. oxalic acid, citric acid, malic acid, succinic acid etc.) in filtrated liquid culture were determined by modern techniques such as HighPerformance Liquid Chromatography (HPLC), Isotachophoresis and enzymatic methods have been used by others to allow more accurate identification of unknown organic acids [6].

This study aimed to isolate PSB from rhizopheric soil, screening them for their solubilization efficiency, HCN, protease, pectinase and cellulase production, characterization and identification of the most efficient isolate which then detected for organic acids production (citric acid, oxalic acid, malice acid, fumaric acid, succinic acid and gibberellic acid) using high performance liquid chromatography(HPLC), then test its ability to stimulate the growth of mung bean (Vigna radita [L.] R.Wilczek) plant.

\section{Material and methods}

\section{Isolation of phosphate solubilizing bacteria}

samples were collected from rhizoferic soils of, wheat, barley, and corn plants from fields in AbuGhraib, Aqraqof , Latifieh,Tarmiah, Jadriya, and College of Agriculture / Baghdad university. The soil suspension was prepared by suspending $10 \mathrm{~g}$ of each soil sample in $100 \mathrm{ml}$ normal saline ( $\mathrm{NaCl} 85 \%$ ) and shaken at $120 \mathrm{rpm}$ for $2 \mathrm{~h}$. The soil suspension was serially diluted followed by spreading of $1 \mathrm{ml}$ of $10^{-3}$ and $10^{-4}$ on National Botanical Research Institute Phosphorus (NBRIP) agar medium $\left(\mathrm{MgCl}_{2} \cdot 6 \mathrm{H}_{2} \mathrm{O} 5 \mathrm{~g}, \mathrm{MgSO}_{4} \cdot \mathrm{H}_{2} \mathrm{O} 0.25 \mathrm{~g}, \mathrm{KCl} 0.2 \mathrm{~g},\left(\mathrm{NH}_{4}\right)_{2} \mathrm{SO}_{4} 0.1 \mathrm{~g}, \mathrm{Ca}_{3}\left(\mathrm{PO}_{4}\right)_{2} 5 \mathrm{~g}\right.$, glucose $10 \mathrm{~g}$, and agar $20.0 \mathrm{~g}$, diluted at1 L distilled water (D.W) at pH 7) [7]. Plates were incubated at $30{ }^{\circ} \mathrm{C}$ for 14 days. Colonies with clear halos were considered as PSB [8]. 


\section{Determination of phosphor solubilizing activity}

Bacterial isolates were screened for their activity to solubilize inorganic phosphate by adding $1 \mu \mathrm{l}$ of $24 \mathrm{~h}$. age cultures on the top of NBRIP media plates. The plates were incubated at $30^{\circ} \mathrm{C}$ for 2 weeks. Solubilization index (SI) was estimated by using the following formula [9]:

$$
\text { Solubilization Index }(\mathrm{SI})=\frac{\text { Diameter of colony }(\mathrm{cm})+\text { halo zone diameter }(\mathrm{cm})}{\text { Diameter of colony }(\mathrm{cm})}
$$

Quantitative estimation of soluble phosphate was done by inoculating $100 \mathrm{ml}$ of NBRIP broth with 24 $\mathrm{h}$, cultured bacteria and incubated in shaker $(180 \mathrm{rpm})$ at $30^{\circ} \mathrm{C}$ for 14 days, control treatment was inoculated with D.W, then centrifuged at $10,000 \mathrm{rpm}$ for $10 \mathrm{~min}$. The supernatant was separated from the bacterial cells by filtration through Whatman No.1 filter paper and used to estimate the released phosphate, from tri-calcium phosphate (TCP), spectrophotometrically (880 nm) [10].

\section{Hydrolytic enzymes, Hydrogen cyanide (HCN), and indole acetic acid(IAA) production}

PSB isolates were activated in NB medium at $30{ }^{\circ} \mathrm{C}$ for $24 \mathrm{~h}$, in order to detect their ability to produce hydrolytic enzymes and $\mathrm{HCN}$ production.

Cellulase production was determined in plates containing Minimal agar (M9) (dextrose $1.0 \mathrm{~g}$, $\mathrm{KH}_{2} \mathrm{PO}_{4} 2.0 \mathrm{~g}, \mathrm{~K}_{2} \mathrm{HPO}_{4} 7.0 \mathrm{~g}, \mathrm{MgSO}_{4} 0.1 \mathrm{~g},\left(\mathrm{NH}_{4}\right)_{2} \mathrm{SO}_{4} 1.0 \mathrm{~g}$, sodium citrate $0.5 \mathrm{~g}$, and agar $20.0 \mathrm{~g}$, dissolved in $1 \mathrm{~L} \mathrm{D.W}$ at $\mathrm{pH} 7.0)$ supplemented with yeast extract $\left(1.2 \mathrm{~g} .1^{-1}\right)$ and carboxy-methyl cellulose $\left(10 \mathrm{~g} \cdot \mathrm{l}^{-1}\right)$. The plates were incubated at $30^{\circ} \mathrm{C}$ for 6 days. Appearance of halo zone indicates a positive result.

Pectinase production was detected in M9 medium containing plates. After inoculation and 3 days of incubation at $30^{\circ} \mathrm{C}$, clear zones formation in the medium represent a positive result [11].

Protease enzyme production was detected in skim milk agar(SM powder $28.0 \mathrm{~g}$, tryptone $5.0 \mathrm{~g}$, yeast extract $2.5 \mathrm{~g}$, dextrose $1.0 \mathrm{~g}$. and agar $15.0 \mathrm{~g}$ ) containing plates, which incubated at $30^{\circ} \mathrm{C}$ for 96 h. Colonies with transparent zones were recorded as protease producing bacteria [12].

$\mathrm{HCN}$ production of the isolates was determined by streaking for $24 \mathrm{~h}$. bacterial culture on plates containing King's B medium (peptone $20.0 \mathrm{~g}, \mathrm{~K}_{2} \mathrm{HPO}_{4} 1.5 \mathrm{~g}, \mathrm{MgSO}_{4}\left(\mathrm{H}_{2} \mathrm{O}\right) 1.50 \mathrm{~g}$ and agar $20.0 \mathrm{~g}$, dissolved in1L D.W at pH 7) supplemented with 4.4 g.L $\mathrm{L}^{-1}$ glycine. Filter paper strips were soaked in solution containing $0.5 \%$ picric acid and $0.2 \%$ sodium carbonate, and then placed in between the plates. The plates incubated at $28^{\circ} \mathrm{C}$ for $48 \mathrm{~h}$. Un inoculated plate were served as control. The change of color of filter paper to orange brown or dark brown indicates a positive result [13].

IAA production was determined by growing PSB isolates on Luria Bertani (LB) broth medium (peptone $10 \mathrm{~g}$, yeast extract $5 \mathrm{~g}$, Nacl $5 \mathrm{~g}$, L-tryptophan $1.2 \mathrm{~g}$, agar $15 \mathrm{~g}$, dissolved in $1 \mathrm{~L} \mathrm{D.W}$ at $\mathrm{pH}$ 7) for 3 days at $30{ }^{\circ} \mathrm{C}$. Then $4 \mathrm{ml}$ of Salkowski reagent $\left(2 \mathrm{ml}\right.$ from $0.5 \mathrm{M} \mathrm{FeCl}_{3}, 49 \mathrm{ml}$ from $70 \%$ perchloric acid and $49 \mathrm{ml} \mathrm{DW}$ ) was added and re-incubated in the dark for $30 \mathrm{~min}$ at $25^{\circ} \mathrm{C}$. Developing of a pink to red color indicates a positive result [14].

\section{Morphological and biochemical identification}

The morphology of colony, margins, shape, raised, pigmentation, and Gram staining were recorded after $24 \mathrm{~h}$ growth at $30{ }^{\circ} \mathrm{C}$ of the most efficient phosphate solubilizing isolate on nutrient agar plates. The isolate was also tested for motility, oxidase, catalase tests, and methyl red production $[9,15$ and $16]$.

\section{Identification by VITEK2}

Bacterial isolate was identified using VITEK2 compact system. The isolate was cultured in NA medium and incubated at $37{ }^{\circ} \mathrm{C}$ for $24 \mathrm{~h}$. The suspensions were prepared in $3 \mathrm{ml}$ of sterile saline and adjusted to a McFarland standard of 1.80-2.20. BCL cards were filled automatically in the instrument vacuum chamber and incubated at $35^{\circ} \mathrm{C}$. Data then analyzed automatically using VITEK2 database.

\section{Determination of organic acid production}

Bacterial isolate was cultured in NBRIP broth $(50 \mathrm{ml})$ and incubated for 5 days at $37{ }^{\circ} \mathrm{C}$. Then the broth culture was centrifuged at $9000 \mathrm{rpm}$ for $15 \mathrm{~min}$ and filtrated through a $0.22 \mu \mathrm{m}$ filter (Millipore, Millex- GP Syringe Filter, SLGP033NB) to obtain a cell-free culture supernatant, non-inoculated broth served as a control [17]. Organic acids were detected with high performance liquid chromatography (HPLC), by injection five $\mu$ of filtered supernatant into HPLC (Agilent model 1260 infinity) with UV detection at $210 \mathrm{~nm}$. The organic acids separation were carried out on a column (Agilent ZORBAX SB C18, $4.6 \mathrm{~mm} \times 250 \mathrm{~mm}, 5 \mu \mathrm{m}$ ) with $0.1 \mathrm{M}$ monopotassium phosphate as mobile phase at a constant flow rate of $0.8 \mathrm{ml} / \mathrm{min}$ (200 bar), $\mathrm{pH}$ of buffer was adjusted to 2.7 at $25^{\circ} \mathrm{C}$ 
oven temperature. Then retention time of organic acids was recorded and compared with the organic acids standard solutions.

\section{Biological experiment}

\section{Inoculum preparation}

Bacterial isolate was grown in $50 \mathrm{ml}$ nutrient broth and incubated at $30{ }^{\circ} \mathrm{C}$ in incubator shaker for $48 \mathrm{~h}$, then centrifuged at $10000 \mathrm{rpm}$ at $4{ }^{\circ} \mathrm{C}$ for $15 \mathrm{~min}$, to collect the bacterial cell. The bacterial suspension was diluted in sterile D.W to a final concentration of $84 \times 10^{8}$ CFU. $\mathrm{ml}^{-1}$ [18].

\section{Seeds preparation}

The seeds of mung bean (Vigna radiate [L.] R. Wilczek), category - local green; procured from General Authority for testing and certification seeds / Abu- Ghraib, were surface sterilized for $10 \mathrm{~min}$ with 5\% sodium hypochlorite solution and then washed thrice with D.W and left for air drying under laminar air flow for $2 \mathrm{~h}$ then, soaked in bacterial cell suspension. The non-soaked seeds were served as control. Furthermore, soaked seeds were air dried inside the laminar air flow for $2 \mathrm{~h}$. and left overnight in the moist chamber [19].

\section{Pots experiment}

Pot experiment was carried out in Agricultural Research office / Abu Ghraib. Plastic pots $(25 \mathrm{~cm}$ diameter) were filled with $8 \mathrm{Kg}$ soil, obtained from Abu Ghraib field. Table-1 showed some of the soil properties, which was silty clay loam. The experiment was conducted with two treatments and three replicates: Control, includes soil and non-inoculated seeds (C) and inoculated treatment, includes soil and seeds inoculated with Bacillus cereus(T). All the treatments were supplied with $50 \mathrm{mg} \mathrm{N} . \mathrm{kg}^{-1}, 160$ mgP. $\mathrm{kg}^{-1}$ and $120 \mathrm{mg} \mathrm{K} . \mathrm{kg}^{-1}$ soil that was applied as urea, Tri-calcium phosphate (TCP), and potassium chlorite respectively, based on the nutrient requirements of mung bean plant. Plant seeds were cultured and covered with $15 \mathrm{~mm}$ thick layer of soil, pots were irrigated during the study period. The plants were harvested after 2 months, and plant growth parameters were analyzed, total plant length, number of branches, fresh weight, and dry weight.

Table 1-Texture and physiological properties of the soil used in the study

\begin{tabular}{|c|c|c|}
\hline Property & Unite & Value \\
\hline Soil PH 1:1 & & 7.3 \\
\hline Electric conductivity EC 1: 1 & ds.m $m^{-1}$ & 3.0 \\
\hline Cation exchange capacity (CEC) & \multirow{4}{*}{$\begin{array}{l}\text { Cmol. kg }{ }^{-1} \\
\text { Soil }\end{array}$} & 23.0 \\
\hline Calcium $\mathrm{Ca}^{+2}$ & & 7.0 \\
\hline MagnesiumMg $^{+2}$ & & 40.0 \\
\hline Sodium $\mathrm{Na}^{+}$ & & 16.0 \\
\hline Nitrogen $\mathrm{N}$ & \multirow{4}{*}{ g. $\mathrm{kg}^{-1}$} & 56.0 \\
\hline Phosphor P & & 26.0 \\
\hline Potassium K & & 46.0 \\
\hline Organic mater & & 138 \\
\hline Sand & \multirow{3}{*}{$\mathrm{g} \cdot \mathrm{kg}^{-1}$} & 176 \\
\hline Silt & & 540 \\
\hline Clay & & 284 \\
\hline
\end{tabular}

\section{Statistical analysis}

Pot experiment was performed with a complete random design (CRD). The data were statistically analyzed using ANOVA. The means of triplicate samples were compared with least significant difference (LSD) values at the level of 0.05 [20].

\section{Results and discussion}

\section{Isolation of PSB}


Out of 16 soil samples obtained, 9 bacterial isolates formed a halo zone around the bacterial colony during growth in NBRIP agar medium (Figure-1), 6 of them were from wheat rhizosphere (Tab. 2).The 9 bacterial isolates were considered as PSB on the basis of their capability to solubilize the insoluble tri-calcium phosphate (TCP) present in NBRIP agar medium [9].

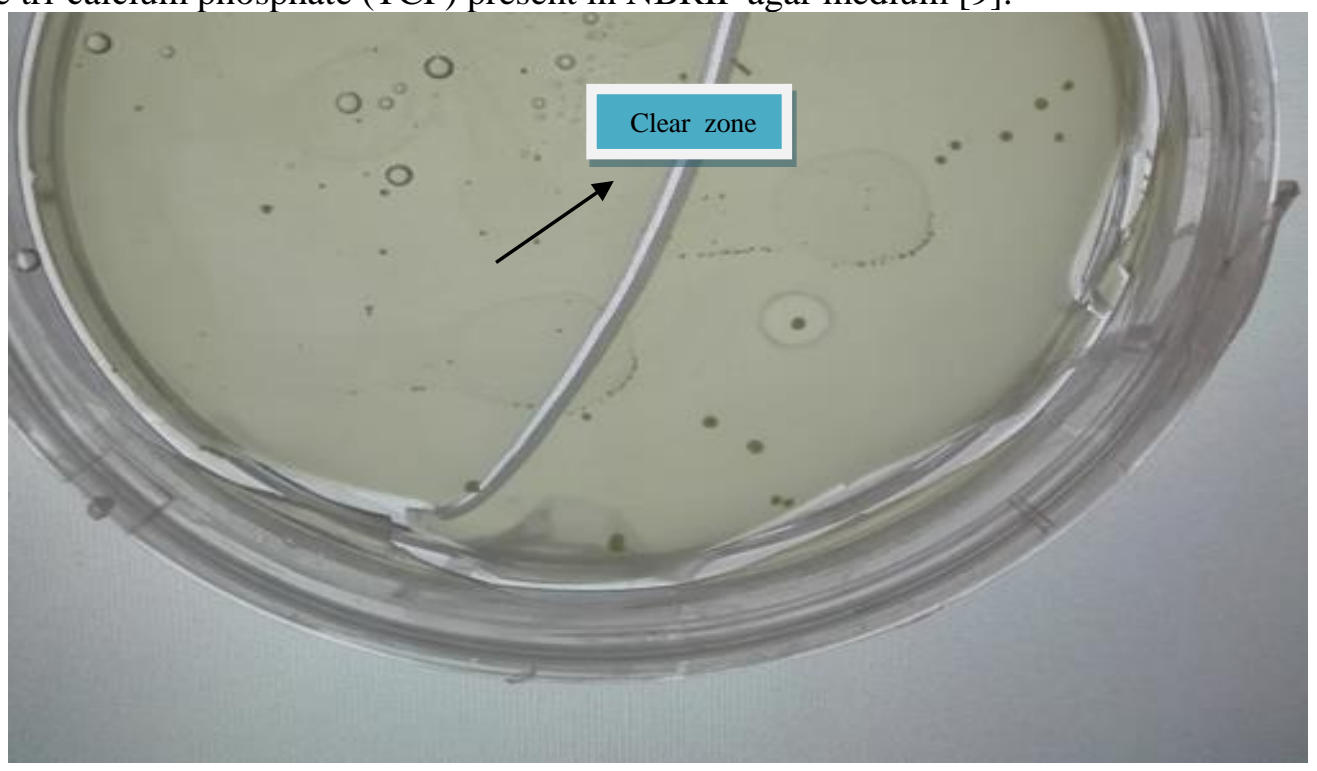

Figure 1-Clear halo zone formation by PSB isolates on NBRIB medium.

Table 2-The sampling area of PSB isolates

\begin{tabular}{|c|c|c|c|}
\hline $\begin{array}{c}\text { No .of } \\
\text { sample }\end{array}$ & Cultured plant & Site & Isolate \\
\hline 1 & Wheat & Tarmiya & Y1 \\
\hline 2 & Wheat & Abu-Ghraib & Y2, Y3 \\
\hline 3 & Barley & Latifieh & Y4 \\
\hline 4 & Wheat & Aqraqof & Y5, Y6 \\
\hline 5 & Barley & Aqraqof & Y7 \\
\hline 6 & yellow corn & Jadriya & Y8 \\
\hline 7 & yellow corn & College of Agriculture & Y9 \\
\hline
\end{tabular}

The nine PSB isolates showed different solubilization abilities (Table-3).The halo zone formed after 2 weeks of incubation in NBRIP agar ranged from $0.3 \mathrm{~cm}$ to $0.8 \mathrm{~cm}, \mathrm{Y} 4$ and Y5 isolates have the widest zone $(0.8 \mathrm{~cm})$ followed by Y2,Y3, and Y6 $(0.7 \mathrm{~cm})$. SI index ranged from 2.00 to 3.66, Y4 isolate reflex the highest value (3.66) followed by Y3 and Y6 (3.33), then Y5 (3.00). The isolates ability to release phosphate (P), from tri-calcium phosphate (TCP), in NBRIP broth ranged from 39.00 to $20.10 \mu \mathrm{g} \cdot \mathrm{ml}^{-1}$, the isolate Y4 showed the highest ability $\left(39.00 \mu \mathrm{g} \cdot \mathrm{ml}^{-1}\right)$ followed by Y3 $(37.00$ $\left.\mu \mathrm{g} \cdot \mathrm{ml}^{-1}\right)$ and Y6 $\left(35.00 \mu \mathrm{g} \cdot \mathrm{ml}^{-1}\right)$.The decline in P-solubilization activity may be due to the nutrients deficiency in the culture medium which needed by phosphate solubilizing bacteria, as a substrates to convert it to organic acid [21]. Some researchers reported a wide variation in the P-solubilization capacities for eight PSB strains which, CBP 2 isolate showed maximum P-solubilization reached $45.96 \mathrm{ppm}$ [22], While others found P-solubilization activity ranged from 0.88 to $24.92 \mu \mathrm{gml}^{-1}$ ) [23]. A widely accepted hypothesis for phosphate solubilization mechanism is that different types of organic acids, including maleic acid, lactic acid, isovaleric acid, isobutyric acid, acetic acid, oxalic acid and citric acid, are being produced which in turn facilitates the solubilization of insoluble phosphates by chelating the cation bound to phosphate, thereby converting it to a soluble form [24]. 
Table 3-Phosphate solubilizing activity for PSB isolates on NBRIP medium

\begin{tabular}{|c|c|c|c|c|}
\hline The isolate & $\begin{array}{c}\text { Halo-zone } \\
\text { diameter }(\mathbf{c m})\end{array}$ & $\begin{array}{c}\text { Colony diameter } \\
(\mathbf{c m})\end{array}$ & SI & $\begin{array}{c}\text { Soluble P (TCP) } \\
\left(\boldsymbol{\mu g . m l ^ { - 1 }}\right)\end{array}$ \\
\hline Y1 & 0.6 & 1.50 & 2.50 & 26.00 \\
\hline Y2 & 0.7 & 1.75 & 2.75 & 25.00 \\
\hline Y3 & 0.7 & 2.33 & 3.33 & 37.00 \\
\hline Y4 & 0.8 & 2.66 & 3.66 & 39.00 \\
\hline Y5 & 0.8 & 2.00 & 3.00 & 28.00 \\
\hline Y6 & 0.7 & 2.33 & 3.33 & 35.00 \\
\hline Y7 & 0.4 & 1.33 & 2.33 & 21.00 \\
\hline Y8 & 0.4 & 1.33 & 2.33 & 21.00 \\
\hline Y9 & 0.3 & 1.00 & 2.00 & 20.10 \\
\hline
\end{tabular}

\section{Production of hydrolytic enzymes, HCN and IAA}

Various PSB features were examined for possible association with the effectiveness of these isolates in the phosphorus solubilization and enhance plant growth, as well as effectiveness against some pathogens. The results showed that, out of 9 isolates, only 7 PSB isolates were able to produce cellulase (Tab. 4), by formation of the clear zone on M9 medium. While all the isolates were able to produce pectinase and protease production through formation of the transparent zone on M9 and skim milk agar plate. Hydrolytic enzymesproduction is important assistance to the antimicrobial potential of antagonists and also have vital roles in the degradation of phytopathogenic micromycetes' cell wall, therefore the synthesis of the hydrolytic enzymes may associate with the antifungal potential. Moreover, some hydrolytic enzymes, such as pectinases, protease, and cellulose, play a substantial role in the stimulation of plant growth, and also contribute to the plant roots colonization by rhizospheric bacteria, the rhizospheric bacteria, such as Pseudomonas and Bacillus genera, exhibited high enzymatic activity and both strains secreted proteinase, amylases, pectinas and cellulases in the suitable conditions and medium [25].

Totally nine isolates showed production of HCN on King's B medium which could contribute to their antifungal activity. The Maximum color change of filter paper strip which soaked in picric acid was shown by Y3 isolate followed by Y4 andY6, while minimum color change was shown by strain Y7, Y8 and Y9.Production of HCN by PSB isolates can inhibit fungal growth and it was reported that Bacillus spp. isolate can inhibit fungal growth by the production of HCN [25].

The ability of IAA production in LB broth medium was found in all PSB isolates, but in different chromatic concentrations, which ranged between pink to red or bulbous color. The maximum color change, compared to control, was recognized in Y4 and Y3 isolates, while the minimum color change was recognized in $\mathrm{Y} 7$ and $\mathrm{Y} 8$ isolates. IAA secreted by some rhizospheric bacteria may directly be involved with the increase of the surface area of the roots which stimulate cell elongation and division, which increases plant uptake of nutrients from the soil. Previous study showed that PSB isolates (JY17 and JY22) improved grape growth by the production of some metabolites facilitating such as IAA, ACC deaminase, and siderophores [26].

Table 4-Production of hydrolytic enzymes, HCN and IAA

\begin{tabular}{|c|c|c|c|c|c|}
\hline The isolates & Cellulase & Pectinase & Protease & HCN & IAA \\
\hline Y1 & - & + & + & ++ & ++ \\
\hline Y2 & - & + & + & ++ & ++ \\
\hline Y3 & + & + & + & ++++ & +++ \\
\hline Y4 & + & + & + & +++ & +++ \\
\hline Y5 & + & + & + & ++ & ++ \\
\hline Y6 & + & + & + & +++ & ++ \\
\hline Y7 & + & + & + & + & + \\
\hline Y8 & + & + & + & + & + \\
\hline Y9 & + & + & + & + & + \\
\hline
\end{tabular}




\section{Identification of PSB isolate}

The isolate Y4 was selected from the nine PSB isolates, depending on the previous tests, because it showed the widest solubilizing halo zone $(0.8 \mathrm{~cm})$, highest SI values (3.66) and the highest ability to release phosphate $\left(39.00 \mu \mathrm{g} \cdot \mathrm{ml}^{-1}\right)$ (Table. 3). The isolate $\mathrm{Y} 4$ was positive for cellulase, pectinase and protease production tests. Moreover, it was able to produce HCN and IAA with high efficiency (Table-5).

Morphological and biochemical tests were performed for Y4 isolate. The obtained isolate was found to be Gram positive, small colony, rod shaped bacteria and also, Showed off-white to creamish colony color when it grown on NA medium. The isolate shows negative results for methyl red and oxidase, and methyl red tests, and positive results for catalase and voges-proskaur. (Table-5). On the basis of these tests, the isolates were closely related to Bacillus genera. Furthermore, Bacillus species isolate was identified, to detect its species, by using VITEK2.

Table 5-Morphological and biochemical properties for selected PSB isolate.

\begin{tabular}{|c|c|}
\hline Biochemical test & Result \\
\hline Pigmenation & off-white to creamish \\
\hline Colony morphology & Smooth margin \\
\hline Cell shape & Rod \\
\hline Motility & Motile \\
\hline Methyl red & $-\mathrm{ve}$ \\
\hline Gram stain & $+\mathrm{ve}$ \\
\hline Voges-proskauer & $+\mathrm{ve}$ \\
\hline Oxidase & $-\mathrm{ve}$ \\
\hline Catalase & $+\mathrm{ve}$ \\
\hline
\end{tabular}

\section{Identified of PSB isolate by VITEC 2 compact system}

The Vitek 2 compact system was used to confirm the diagnosis of the PSB isolate under study, the identified isolate was related to Bacillus cereus with a probability of $91 \%$, as illustrated in (Table-6). Vitek 2 compact system, a development of - API -20, records the chromatic changes as a result of bacterial growth.

Table 6-Identification of Bacillus sereus using Vitek 2 compact system

\begin{tabular}{|l|ll|ll|}
\hline Identification Information & Analysis Time: & 13.87 hours & Status: & Final \\
\hline \multirow{2}{*}{ Selected Organism } & $91 \%$ Probability & Bacillus cereus & & \\
& Bionumber: & 0727101240456661 & \\
\hline ID Analysis Messages & & & \\
\hline
\end{tabular}

\begin{tabular}{|l|l|l|l|l|l|l|l|l|l|l|l|l|l|l|l|l|l|}
\hline \multicolumn{10}{|l|}{ Biochemical Details } \\
\hline 1 & BXYL & - & 3 & LysA & - & 4 & AspA & $-(-)$ & 5 & LeuA & + & 7 & PheA & + & 8 & PrOA & + \\
\hline 9 & BGAL & - & 10 & PyrA & + & 11 & AGAL & - & 12 & AlaA & + & 13 & TyrA & + & 14 & BNAG & + \\
\hline 15 & APPA & + & 18 & CDEX & - & 19 & dGAL & - & 21 & GLYG & - & 22 & INO & - & 24 & MdG & - \\
\hline 25 & ELLM & + & 26 & MdX & - & 27 & AMAN & - & 29 & MTE & -- & 30 & GlyA & + & 31 & dMAN & - \\
\hline 32 & dMNE & - & 34 & dMLZ & - & 36 & NAG & + & 37 & PLE & - & 39 & RHA & - & 41 & BGLU & - \\
\hline 43 & BMAN & - & 44 & PHC & - & 45 & PVATE & + & 46 & AGLU & + & 47 & dTAG & - & 48 & dTRE & + \\
\hline 50 & INU & - & 53 & dGLU & + & 54 & dRIB & + & 56 & PSCNa & - & 58 & NaCl $6.5 \%$ & + & 59 & KAN & + \\
\hline 60 & OLD & - & 61 & ESC & + & 62 & TTZ & + & 63 & POLYB_R & + & & & & & & \\
\hline
\end{tabular}




\section{Detection of organic acid}

Bacillus cereus ability to produce organic acids in the NBRIP broth medium was determined by HPLC with wavelength $210 \mathrm{~nm}$. The results in Figure-2 illustrated 12 peaks for different organic acids (Appendix 1 and 2).

Three major peaks (Table-7) were detected for oxalic acid (2.996), citric acid (9.117), and malic acid (3.734) by comparing their retention times with those of the authentic standards (Appendix 3,4,and 5).

These results demonstrated that the production of low-molecular organic acids such as oxalic acid, malic acid, succinic acid, tartaric acid and citric acid by acid-producing Bacillus strain could significantly increase the mobility and bioavailability of phosphorus by bonding such heavy metals as $\mathrm{Fe}, \mathrm{Mn}, \mathrm{Zn}, \mathrm{Cu}, \mathrm{Cd}, \mathrm{Pb}$ through acidification, chelating, sedimentation and oxidation reduction [27].

Furthermore, secretion of citric acid by PSB isolates can improve their P-solubilizing efficiency [26]. Researchers incorporated artificial citrate operon that contained 2 genes; NADH insensitive citrate syntheses (gltA1) and citrate transporter (citC) genes, into the genomes of Pseudomonas fluorescence [28] and Enterobacter hormaechei strains [29], founding that the hybrids strains have more efficacy to secrete more citric acid than the native strains, therefore they released more soluble $\mathrm{P}$ in the mediums.

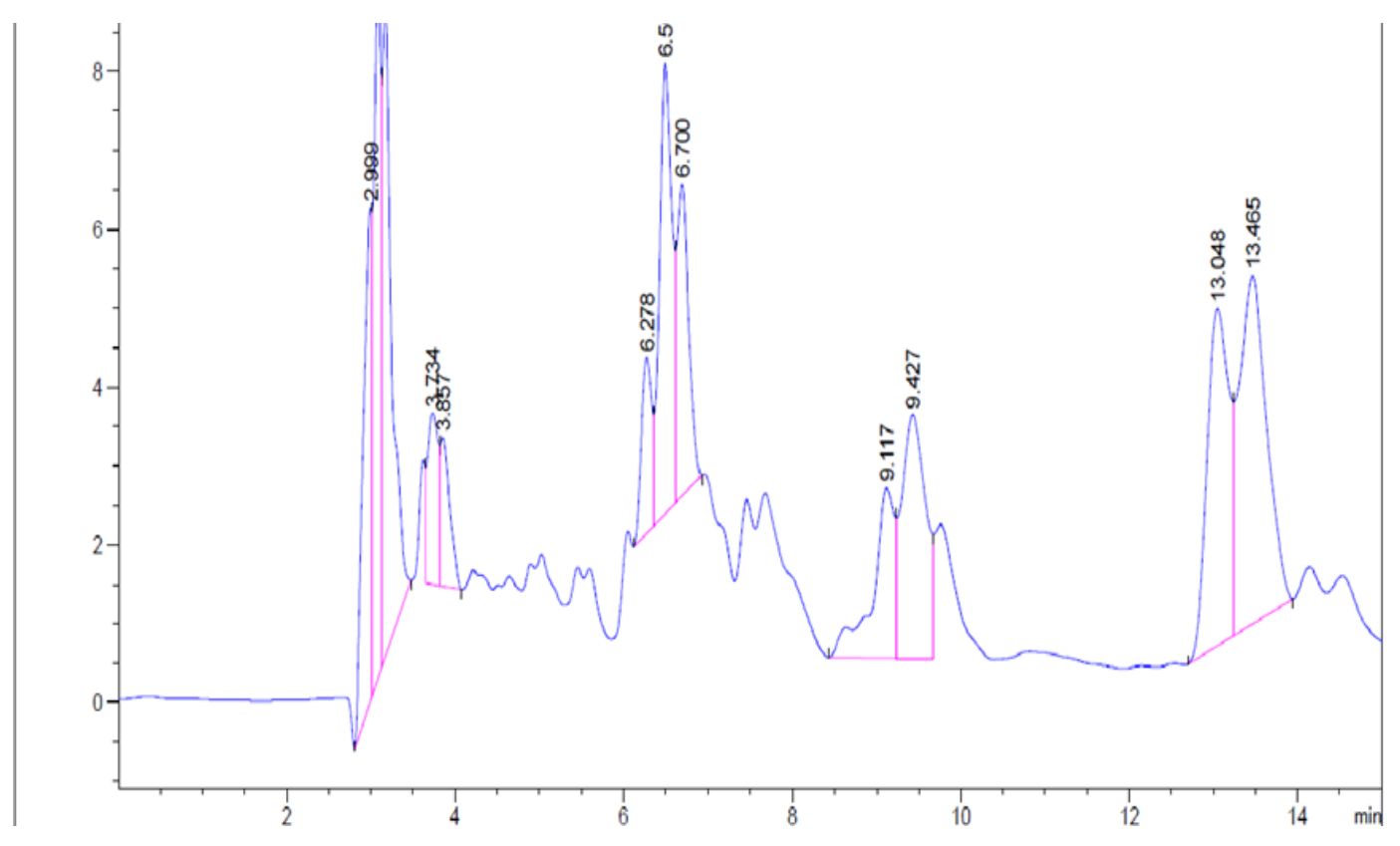

Figure 2-The organic acids produced by Bacillus cereus, HPLC chromatogram

Table 7-Production of organic acids in NBRIP medium by Bacillus cereus

\begin{tabular}{|c|c|c|}
\hline $\begin{array}{c}\text { Sr. } \\
\text { No }\end{array}$ & Organic acid & Retention time (min.) \\
\hline 1 & Oxalic acid & 2.996 \\
\hline 2 & Citric acid & 9.117 \\
\hline 3 & Malic acid & 3.734 \\
\hline
\end{tabular}

This results demonstrated that the production of low-molecular organic acids such as oxalic acid, malic acid, succinic acid, tartaric acid and citric acid by acid-producing Bacillus strain could significantly increase the mobility and bioavailability of phosphorus by bonding such heavy metals as $\mathrm{Fe}, \mathrm{Mn}, \mathrm{Zn}, \mathrm{Cu}, \mathrm{Cd}, \mathrm{Pb}$ through acidification, chelating, sedimentation and oxidation reduction [27].

\section{Pot experiments}

The effect of Bacillus cereus isolate on mung bean plant as inoculum, was detected in biological experiment. Inoculated plants illustrated a significant increase in branches number (12.33), plant length $(83.0 \mathrm{~cm})$, fresh weight $(27.25 \mathrm{~g})$ and dray weight $(1.427 \mathrm{~g})$ compared with control treatments, after 2 months of growth (Table- 8). These increases in inoculated plants may be due to enhancing the 
amount of soluble P presence in the soil which in turn increase the uptake of $\mathrm{P}$ by mung bean plants or suppress many diseases caused by different phytopathogens [26, 30].

Aloe barbadensis treated with PSB isolates were increased in P content, especially in leaves, and consequently all the growth parameters, including leaf length, root length, drying weight, were elevated [31]. The previous study found that PSB isolates increased the height, stem thickness and root and shoot dry weight of Cabernet Sauvignon(Vitis viniferacv) [26].

Table 8-The effects of Bacillus cereus inoculum on mung bean growth

\begin{tabular}{|c|c|c|c|}
\hline The treatments & C & T & $\begin{array}{c}\text { LSD } \\
\text { Growth parameter }\end{array}$ \\
\hline Number of branckes & $7.33 \pm 1.000$ & $12.33 \pm 1.000$ & 4.3030 \\
\hline Plant length $(\mathrm{cm})$ & $43.3 \pm 2.91$ & $83.0 \pm 2.91$ & 12.50 \\
\hline Fresh weight(g) & $23.08 \pm 3.132$ & $27.25 \pm 3.132$ & 3.1320 \\
\hline Dry weight( Mg/plant) & $0.867 \pm 0.0651$ & $1.427 \pm 0.0651$ & 0.2799 \\
\hline
\end{tabular}

Values are given as means of triplicate samples \pm S.E

\section{Conclusion}

The ability of PSB isolates to convert insoluble phosphorus to a soluble form, is an important trait of phosphate solubilizing bacteria to overcome the problem of deficiency of available phosphor as a result of chemical fertilizers addition to soil. Phosphorus is a master key for plants nutrition, but it is often not available due to its fixation in soil. PSB are beneficial rhizobacteria with all their mechanisms as plant growth promoting bacteria, such as phosphate solubilization, antifungal and production of HCN, plant growth regulators (auxins, cytokinins and gibberellins) and lytic enzymes. Nine PSB isolates were able to solubilize tri-calcium phosphate presence in NBRIP media, most of them were also able to produce cellulase, pectinase, protease, IAA and HCN. Bacillus sereus was the most efficient phosphate solubilizing bacteria, by producing high levels of P- solubilization and other plant growth promoting activities. The organic acids producing by this isolate have the most important role in the mechanism of phosphate solubilization which in turn improves mung bean (Vigna radita [L.] R. Wilczek) plant growth parameters.

\section{Acknowledgment}

The authors acknowledge with thanks the Agricultural Research Office/Abu Graib, Baghdad, and Ministry of Science and Technology /Department of researches/ Baghdad, for their contribution and help during the research period.

\section{References}

1. Guan-Xi Li,Xiao-Qin Wu, Jian-Ren Ye. and He-Chuan Yang .2018. Characteristics of Organic Acid Secretion Associated with the Interaction between Burkholderia multivorans WS-FJ9 and Poplar Root System. BioMed Research International. https://doi.org/10.1155/2018/9619724.

2. Naqqash, T., Hameed, S., Imran, A. and Hanif, M. 2016. Differential response of potato toward inoculation with taxonomically diverse plant growth promoting rhizobacteria. Front. Plant Sci, 7: 144. https://doi.org/10.3389/fpls.2016.00144.

3. Meena, M., Dubey, M.K., Singh, S., Kumari, P., Upadhyay, R.S., Swapnil, P. and Zehra, A. 2017. The rhizosphere microbial community and methods of its analysis. In: Singh,H.B., Sarma, B.K., Keswani, C. (Eds.), Advancement in PGPR Research. CABI, 277-278.

4. Khan, M. S., Zaidi, A. and Ahmad, E. 2014. Mechanism of phosphate solubilisation and physiological functions of phosphate-solubilizing microorganisms. In M. S. Khan, A. Zaidi, and J. Mussarrat (Eds.),Phosphatesolubilizing microorganisms. London, UK: Springer. 31-62. https://doi.org/10.1007/978-3-319-08216-5_2.

5. Marra, L. M., Soares, C. R. F. S. S., de Oliveira, S. M., Ferreira, P. A. A. A., Soares, B. L. and Carvalho, R. F.,Moreira, F. M. 2012. Biological nitrogenfixation and phosphate solubilization by bacteria isolated from tropical soils. Plant and Soil. (357): 289-307. https://doi.org /10.1007 /s11104-012-1157-z. 
6. Mehta. A.C. D.D. Malavia, and B.B.Kaneriaand VD Khanpara. 1996. Response of groundnut(Arachishypogaea) to farmyard manure, phosphorus and phosphate- solubilizing micro-organism. Indian J Agron, 41: 172-174. https://doi.org/10.1016/j.bcab.2013.09.008.

7. Nautiyal, C.S. 1999. An efficient microbiological growth medium for screening phosphorus solubilizing microorganisms. FEMS Microbiol. Lett. 170: 2017-2021. https://doi.org/10.1111 lj.1574-6968.1999.tb13383.x.

8. Behera BC, Singdevsachan SK, Mishra RR, Dutta SK, Thatoi HN. 2014. Diversity, mechanism and biotechnology of phosphate solubilising microorganism in mangrove - A review. Biocatalysis and Agricultural Biotechnology, 3: 97-110.

9. Sadiq, H.M., Jahangir, G.Z., Nasir, I.A., Iqtidar, M. and Iqbal, M. 2013. Isolation and characterization of phosphate-solubilizing bacteria from rhizosphere soil. Biotechnology \& Biotechnological Equipment, 27(6): 4248-4255. https://doi.org/10.5504/BBEQ.2013.0091.

10. Murphy J. and Riley J. P. 1962. A modified single solution method for determination of phosphate in natural waters. Analytica Chimica Acta, 27: 31-36. https://doi.org/10.1016/S00032670(00)88444-5.

11. Cattelan, A . J., Hartel, P. G. and J. J. Fuhrmann. 1999. Screening For Plant Growth-Promoting Rhizobacteria To Promote Early Soybean Growth. Soil Science Society of America journal, 63: 1670-168. doi:10.2136/sssaj1999.6361670x.

12. Folasade, M. O. and O. A. Joshua. 2008. Some properties of extracellular protease from Bacillus licheniformis Lbb1-11 isolated from 'iru', A traditionally fermented African locust bean condiment. J. Biotechnol. Biochem. 3: 42-46. https://academicjournals.org/journal/AJBR/articlefull-text-pdf/5F6025A10198.

13. Ayyadurai, N., Ravindra Naik, P. and Sakthivel, N. 2007. Functional characterization of antagonistic fluorescent pseudomonas associated with rhizospheric soil of rice (Oryza sativa L.). $J$. Microbiol. Biotechnol. 17: 919-927. https://europepmc.org/authors/0000-0002-7333-6344.

14. Bric J. M., Bostock R. M. and Silverstone S. E. 1991. Rapid In-Situ assay for indole-acetic acid production by bacteria immobilized on a nitrocellulose membrane. Appl. Environ. Microbiol. 57: 535-538.

15. Collee, J.G. and Marr, W. 1996. Culture of Bacteria In: Mackie and McCartney Practical Microbiology by Collee, J.G.; Fraser, A.G.;Marmion, B.P.; and Simmons, A. 4th ed. Churchill, Livingstone.

16. Shahzaman, S. 2014. Preliminary screening for fungal root pathogensuppression by plant growth promoting rhizobacteria in(ChickpeaCicerarietinum L.). J. of Agril. Sci., 4(6): 295-298.

17. Vazquez, F., Ramaswamy, S., Nakamura, N. and Sellers, W.R. 2000. Phosphorylation of the PTEN tail regulates protein stability and function. Molecular and cellular biology, 20(14): 50105018. DOI: $10.1128 / \mathrm{MCB} .20 .14 .5010-5018.2000$.

18. Mortensen, R.M., Conner, D.A., Chao, S. and Geisterfer-Lowrance, A.1992. Production of homozygous mutant ES cells with a single targeting construct. Mol. Cell Biol. 12: 2391-2395. DOI: 10.1128/MCB.12.5.2391.

19. Singh, A., Jain, A., Sarma, B.K. and Upadhyay, R.S. 2013. Rhizosphere microbes facilitate redox homeostasis in Cicerarietinum against biotic stress. Ann. Appl. Biol. 163: 33-46. https://doi.org /10.1111/aab.12030.

20. SAS. 2012. Statistical Analysis System, User's Guide. Statistical. Version $9.1^{\text {th }}$ ed. SAS. Inst. Inc. Cary. N.C. USA.

21. Sharma, S.B., Sayyed, R.Z., Trivedi, M.H. and Gobi, T.A. 2013. Phosphate solubilizing microbes: sustainable approach for managing phosphorus deficiency in agricultural soils . Springer Plus, 2(1): 587. https://doi.org/10.1186/2193-1801-2-587.

22. Baliah, N.T. and Begum, P.J. 2015. Isolation, identification and characterization of phosphate solubilizing bacteria (PSB) isolated from economically important crop plants. Int. J. Curr. Microbiol. App. Sci, 4(3): 915-924. https://pdfs.semanticscholar.org/5db9/a95fb626f439dcadef2b4c515beb7f84e2dc.pdf.

23. Satyendra Kumar Jha .2016. Characterization of Phosphate Solubilising and Mineralizing Bacteria From Grain Legumes, L-2014-BS-304-M. 
24. Paul, D. and Sinha, S. N. 2017. Isolation and characterization of phosphate solubilizing bacterium Pseudomonas aeruginosaKUPSB12 with antibacterial potential from river Ganga, India. Annals of Agrarian Science, 15: 130-136. https://doi.org/10.1016/j.aasci.2016.10.001.

25. Mardanova, A.M., Hadieva, G.F., Lutfullin, M.T., Khilyas, I.V., Minnullina, L.F., Gilyazeva, A.G., Bogomolnaya, L.M. and Sharipova, M.R. 2017. Bacillus subtilis Strains with Antifungal Activity against the Phytopathogenic Fungi. Agricultural Sciences, 8:1-20. DOI:10.4236 las.2017.81001.

26. Min Liu, Xu Liu, Bao-Sen Cheng, Xue-Lei Ma, Xiao-Tong Lyu, Xian-Fang Zhao, Yan-Lun Ju, Zhuo Min, and Yu-Lin Fang. 2016. Selection and evaluation of phosphate-solubilizing bacteriafrom grapevine rhizospheres for use as biofertilizers. Spanish Journal of Agricultural Research. 14(4). DOI: 10.5424/sjar/2016144-9714.

27. Zhong, C., Jiang, A., Huang, W., Qi, X. and Cao, G. 2017, May. Studies on the acidproduction characteristics of Bacillus megaterium strain P17. In AIP Conference Proceedings, 1(1839): 020054. https://aip.scitation.org/doi/abs/10.1063/1.4982419.

28. Adhikary H, Sanghavi PB, Macwan SR, Archana G. and Kumar, GN. 2014. Artificial citrate operon confers mineral phosphate solubilization ability to diverse Fluorescent pseudomonads. Plos One. 9(9): 1-12. https://doi.org/10.1371/journal.pone.0107554.

29. adav K, Kumar C, Archana G, Kumar GN. 2014. Artificial citrate operon and Vitreoscilla hemoglobin gene enhanced mineral phosphate solubilizing ability of Enterobacter hormaechei Dhrss. Appl Microbiol Biotechnol. 98(19): 8327-8336. https://doi.org/10.1007/s00253-014-59123.

30. Punam Kumari, Mukesh Meena, Pooja Guptad, Manish Kumar Dubey, Gopal Nath,R.S. and Upadhyay. 2018. Plant growth promoting rhizobacteria and their biopriming for growth promotion in mung bean (Vigna radiata (L.) R. Wilczek). Biocatalysis and Agricultural Biotechnology. 16: $163-171$.

31. Gupta, M., Kiran, S., Gulati, A., Singh, B. and Tewari R. 2012. Isolation and identification of phosphate solubilizing bacteria able to enhance the growth and aloin-a biosynthesis of Aloe barbadensis Miller. Microbiol Res. 167(6): 358-363. 